\title{
Haematological And Biochemical Changes Induced By Amaranth Impact On Male Albino Rats
}

\author{
Shadia Ali Radwan; Ahmed Riad El-Sayed; Mohammed Salah Al-Shinnawy and \\ Omnia Nasr Abdel-Rahman Mohamed \\ Department of Biological and Geological Sciences, Faculty of Education, \\ Ain Shams University
}

\begin{abstract}
The present investigation was performed to study the effect of daily administration (interperitoneal injection) of synthetic coloring agent amaranth at dose $50 \mathrm{mg} / \mathrm{kg} \mathrm{b}$.w. /day for two periods (7 and 21 days), using male albino rats. The effects of amaranth on growth, haematological and some biochemical parameters were examined throughout the study. The results revealed that amaranth treatment cause a marked change in treated groups when compared with control. They showed a significant decrease in percentage of body weight change, RBCs count, Hb concentration and HCT value, while, they recorded a significant increase in WBCs, serum activity of AST and ALP, in addition to serum urea and creatinine levels in treated rats. But ALT and bilirubin showed insignificant changes throughout the experiment.
\end{abstract}

Key words: food additives, amaranth, haematological, biochemical, parameters, albino rats.

\section{Introduction}

According to the Food Protection Committee of Food and Nutrition Board, food additives may be defined as substances or a mixture of substances, other than the basic food-stuffs, which are found in the foods as a result of any aspect of production, processing, storage or packaging. Food additives are used for various purposes, including preservation, coloring or sweetening. The wide range of food additives, running into more than 2500 items used to preserve, dye or enhance foods are a consequence of industrialization and the development of food processing technology. Most coloring agents are used to improve the overall attractiveness of food. A number of natural and synthetic additives are used to color foods. Although synthetic coloring agents are continued to be used extensively, there has been a concomitant significant increasing interest concerning the using of natural colorants.

Azo dyes are one of these food additives which widely used as food colorants. They account for approximately
$60-70 \%$ of all dyes used in food and textile manufacture. Azo dyes are much more stable than most of the natural food dyes. They are stable in the whole $\mathrm{pH}$ range of foods, are heat stable and do not fade when exposed to light or oxygen. This makes azo dyes applicable in nearly all foods.

Despite the benefits attributed to food additives, for several years there have also been a number of concerns regarding the potential short- and long-term risks of consuming these substances. Criticisms of these food additives are concerned with both indirect and direct impacts of using them. More attention was focused on the pathophysiological effects of coloring additives. The biochemical and histopathological examinations of the toxic effects of synthetic dyes were tested. There has been an extensive ongoing research on the deleterious effects induced by synthetic food coloring agents in rats (Paumgartten et al., 2002; Kitamura et al., 2003; Bautista et al., 2004 and Attia et al., 2005). 
Amaranth (FD\&C Red No.2) is one of the most widely tested dyes, which used in food, drugs, soft drinks, jellies, sweets and cosmetics. Some studies have suggested that amaranth, is carcinogenic in rats (Wilheim and Ivy, 1953 and Andrianova, 1970) and affects their reproduction (Collins and McLaughlin, 1972; Collins and McLaughlin, 1973 and Collins et al., 1975a, b). Amaranth is also considered as teratogenic agent to small mammals such as mice or rats and was banned by the United States Federal Drug Administration in 1976 for use in drugs, cosmetics, or foods. The International Agency for Research on Cancer (IARC) suggests that there is no enough evidence to conclusively state that amaranth is a human carcinogenic.

The present work is aimed to carry out some haematological and biochemical investigations on male albino rats to study the various effects of a synthetic food colorant agent (amaranth), which present on a wide-scale basis in the food-marketing industry.

\section{Materials and methods}

\section{The Experimental Animals}

Two main groups of male albino rats were obtained from Schistosoma Biological Supply Program (SBSP) Theodor Bilharz Research Institute, each group was contained 28 rat. Each rat in the first group is weighing about $60 \mathrm{gm}$, while in the second group weighing about $120 \mathrm{gm}$ at the beginning of the experiment. Each two rats were placed in a metal cage. They were kept under normal laboratory conditions during the whole period of experimentation. All animals were fed on standard diet. Food and water were available ad libitum. All rats were starved for $12 \mathrm{hrs}$ before sacrifice, but allowed free excess of water.

\section{Synthetic dye used}

Amaranth (E123) the synthetic food colorant agent used in the present investigation.

The synthetic azo dye-red food color- is very soluble in water.

-Chemical name: 3-hydroxy-4-[C $\mathrm{C}_{4}$-sulfo-1-naphthalenylazo]-2,7-napthalenedisulphonic acid, trisodium salt.

-INS: 123-(915-67-3)-Dye content-1010570.

-MW: 604.46

-Formula: $\mathrm{C}_{20} \mathrm{H}_{11} \mathrm{~N}_{2} \mathrm{Na}_{3} \mathrm{O}_{10} \mathrm{~S}_{3}$

\section{Dosage and administration}

Each treated rat received $50 \mathrm{mg} / \mathrm{kg}$. b.w. of amaranth daily via intraperitoneal injection.

\section{Pattern and periods of the experiment}

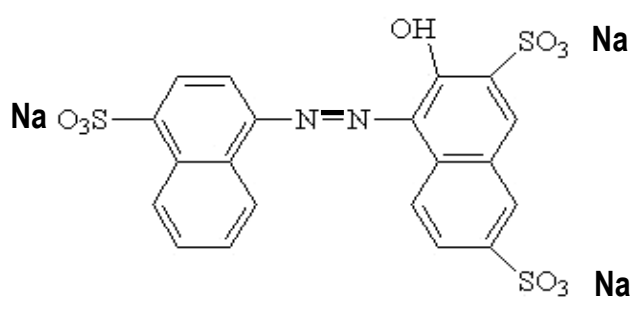

Structural formula of Amaranth follows:

Each main group of male albino rats was allocated into four subgroups of 7 rats each, as

- The first subgroup, was conserved as a control and kept under the same laboratory conditions and was intraperitoneal daily injected with $1 \mathrm{ml}$ distilled water for a period of seven days.

- The second subgroup, was intraperitoneal daily injected with $1 \mathrm{ml} \mathrm{of} 50 \mathrm{mg} / \mathrm{kg}$ body weight of amaranth for a period of seven days.

- The third subgroup, was served as a control for another period equal to 21 days with 1 $m l$ distilled water.

- The forth subgroup, of 7 rats were intraperitoneal daily injected with the same dose of amaranth for a period equal 21 days. 
By the end of the two periods, the animals (both control and treated ones) were sacrificed and blood samples were collected for haematological and biochemical investigations.

\section{1-Percentage of mean body weight change}

All of the control and treated rats were individually weighed in order to detect any change that may takes place in their body weights. The percentage of body weight change was calculated as follows:

$$
\frac{\text { Mean final weight }- \text { Mean initial weight }}{\text { Mean initial body weight }} \times 100
$$

\section{2-Haematological studies}

Blood samples were collected on heparinized capillary tubes for haermatocrit value (Hct) or packed cell volume (PCV) represents the percentage of red cells volume of whole blood. It is measured after allowing the blood to enter a capillary tube that is plugged by plastic seal and centrifuged at 1200 r.p.m. for 5 min. (Rodak, 1995).

Red and white blood cells were counted using improved haemocytometer according to Dacie and Lewis (1991). Haemoglobin concentration was recorded in $\mathrm{gm} / \mathrm{dl} \mathrm{blood}$, and it was estimated according to Dacie and Lewis (1991).

Also, the mean corpuscular volume (MCV), the mean corpuscular haemoglobin $(\mathrm{MCH})$ and The mean corpuscular haemoglobin concentration (MCHC) were calculated according to Dacie and Lewis (1993) using the following equations:

$$
\begin{aligned}
& \mathrm{MCV}=\frac{\text { Haematocrit value }(\%)}{\text { Red blood cells count }\left(\text { million/ } / \mathrm{mm}^{3}\right)} \times 10 \quad(\mathrm{pg}) \\
& \mathrm{MCH}=\frac{\text { Haemoglobin content }(\mathrm{g} / 100 \mathrm{ml} \text { blood })}{\text { Red blood cells count }\left(\mathrm{million} / \mathrm{mm}^{3}\right)} \times 10 \quad(\mathrm{pg}) \\
& \mathrm{MCHC}=\frac{\text { Haemoglobin content }(\mathrm{g} / 100 \mathrm{ml} \mathrm{blood})}{\text { Haematocrit value }(\%)} \times 100 \%
\end{aligned}
$$

\section{3- Biochemical studies}

- Aspartate aminotransferase (AST) \& Alanine aminotransferase (ALT) activities were estimated according to Bergmeyer and Horder (1986).

- While, Alkaline phosphatase (ALP) activity was estimated according to Abicht et al. (2001).

-Serum content of urea was estimated according to the method described by Neumann et al. (1977).

-Beside, Serum creatinine was determined according to the method described by Bartels et. al. (1972).
-Serum uric acid content was determined according to the method described by Town et al. (1985).

The obtained results were statistically analyzed by using the student " $\mathrm{t}$ " test according to the method of Snedecore and Cochran (1980).

\section{Results}

I- Effect of amaranth on percentage of body weight change

The effect of repeated doses of amaranth on percentage of body weight change of the rats is recorded in table (1). The findings revealed a significant $(\mathrm{p}<0.05)$ decrease in group (1) after 7 days and groups (1), (2) after 21 days. 
Table (1): Effect of amaranth on the percentage of body weight change of male albino rats.

\begin{tabular}{|c||c||c|c|c|}
\hline \multirow{2}{*}{ Group } & \multicolumn{2}{|c|}{ After 7 days } & \multicolumn{2}{c|}{ After 21 days } \\
\cline { 2 - 5 } & Control & Treated & Control & Treated \\
\hline \hline$(\mathbf{1})$ & $16.667 \pm 0.578$ & $14.762 \pm 0.289^{*}$ & $58.809 \pm 0.298$ & $57.619 \pm 0.232^{*}$ \\
\hline \hline \% of change & \multicolumn{2}{|c|}{-11.429} & \multicolumn{2}{|c|}{-2.023} \\
\hline $\mathbf{( 2 )}$ & $15.238 \pm 0.089$ & $15.119 \pm 0.082$ & $37.619 \pm 0.082$ & $37.071 \pm 0.137^{*}$ \\
\hline \hline \% of change & \multicolumn{2}{|c|}{-0.781} & \multicolumn{2}{|c|}{-1.457} \\
\hline \hline
\end{tabular}

Group (1): Rats with mean initial weight $=60 \mathrm{gm}$.

*(Significant)

Group (2): Rats with mean initial weight $=120 \mathrm{gm}$.

- All values were expressed as mean \pm standard error.

\section{2- Effect of amaranth on haematological parameters}

\section{a- Red blood cells( RBCs) count}

Results presented in table (2) showed the alteration of RBCs count of rats treated with amaranth. The erythrocytes count revealed a highly significant decrease $(p<0.01)$ in group (1) after 7 days, and after 21 days. Also, showed a significant decrease $(\mathrm{p}<0.05)$ in group (2) after 7 days. But the red blood cells count in second group after 21 days were markedly highly significant increased $(\mathrm{p}<0.01)$.

Table (2): Effect of amaranth on RBCs count $\left(\times 10^{6} \mathrm{~mm}^{3}\right)$ of male albino rats.

\begin{tabular}{|c|c|c|c|c|}
\hline \multirow{2}{*}{ Group } & \multicolumn{2}{|c|}{ After 7 days } & \multicolumn{2}{|c|}{ After 21 days } \\
\hline & Control & Treated & Control & Treated \\
\hline (1) & $\begin{array}{l}7.071 \pm 0.171 \\
\end{array}$ & $5.914 \pm 0.114^{* * *}$ & $7.357 \pm 0.065$ & $6.574 \pm 0.099$ \\
\hline \% of change & \multicolumn{2}{|c|}{-16.363} & \multicolumn{2}{|c|}{-10.643} \\
\hline$(2)$ & $7.000 \pm 0.038$ & $6.571 \pm 0.106^{*}$ & $7.329 \pm 0.102$ & $8.300 \pm 0.079$ \\
\hline \% of change & \multicolumn{2}{|c|}{-6.128} & \multicolumn{2}{|c|}{+13.249} \\
\hline
\end{tabular}

Group (1): Rats with mean initial weight $=60 \mathrm{gm}$.

*(Significant) $\quad * *($ Highly significant)

Group (2): Rats with mean initial weight $=120 \mathrm{gm}$.

- All values were expressed as mean \pm standard error. 


\section{b- Haemoglobin concentration $(\mathrm{Hb})$}

The data represented in table (3) revealed a significant decrease $(\mathrm{p}<0.05)$ on $(\mathrm{Hb})$ in groups $(1)$ and (2) after 7 days. Also, a highly significant decrease $(\mathrm{p}<0.01)$ of haemoglobin concentration was showed in group (1) after 21 days. On the other hand group (2) after 21 days reveals a highly significant $(\mathrm{p}<0.01)$ increased.

Table (3): Effect of amaranth on haemoglobin $(\mathrm{Hb})$ concentration (g/dl) of male albino rats.

\begin{tabular}{|c|c|c|c|c|}
\hline \multirow{2}{*}{ Group } & \multicolumn{2}{|c|}{ After 7 days } & \multicolumn{2}{|c|}{ After 21 days } \\
\hline & Control & Treated & Control & Treated \\
\hline (1) & $12.929 \pm 0.301$ & $9.857 \pm 0.670^{*}$ & $14.057 \pm 0.134$ & $12.614 \pm 0.077^{* * *}$ \\
\hline \% of change & \multicolumn{2}{|c|}{-23.76} & \multicolumn{2}{|c|}{-10.265} \\
\hline (2) & $13.271 \pm 0.090$ & $12.671 \pm 0.169^{*}$ & 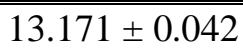 & $15.057 \pm 0.207^{* * *}$ \\
\hline$\%$ of change & \multicolumn{2}{|c|}{-4.521} & \multicolumn{2}{|c|}{+14.319} \\
\hline
\end{tabular}

Group (1): Rats with mean initial weight $=60 \mathrm{gm}$.

* (Significant) ** (Highly significant)

Group (2): Rats with mean initial weight $=120 \mathrm{gm}$.

- All values were expressed as mean \pm standard error.

\section{c- Haematocrit value (Hct)}

The findings in table (4) revealed a highly significant decrease $(\mathrm{p}<0.01)$ on haematocrit value (Hct) in group (1) after 21 days, while the results of group (2) after 21 days represented a highly significant increase $(\mathrm{p}<0.01)$.

Table (4): Effect of amaranth on Hct value (\%) of male albino rats.

\begin{tabular}{|c|c|c|c|c|}
\hline \multirow{2}{*}{ Group } & \multicolumn{2}{|c|}{ After 7 days } & \multicolumn{2}{|c|}{ After 21 days } \\
\hline & Control & Treated & Control & Treated \\
\hline (1) & $35.943 \pm 2.163$ & $34.429 \pm 0.685$ & $40.114 \pm 0.297$ & $38.214 \pm 0.134^{*}$ \\
\hline \% of change & \multicolumn{2}{|c|}{-4.212} & \multicolumn{2}{|c|}{-4.736} \\
\hline (2) & $40.829 \pm 0.164$ & $39.886 \pm 0.708$ & $40.843 \pm 0.115$ & $46.400 \pm 0.419^{*}$ \\
\hline$\%$ of change & \multicolumn{2}{|c|}{-2.309} & \multicolumn{2}{|c|}{+13.606} \\
\hline
\end{tabular}

Group (1): Rats with mean initial weight $=60 \mathrm{gm}$. **(Highly significant)

Group (2): Rats with mean initial weight $=120 \mathrm{gm}$.

- All values were expressed as mean \pm standard error. 
Table (5) showed a highly significant increase $(\mathrm{p}<0.01)$ of the mean corpuscular volume in group (1) after 7 days and group (2) after 21 days.

Table (5): Effect of amaranth on MCV (fl) of male albino rats.

\begin{tabular}{|c|c|c|c|c|}
\hline \multirow{2}{*}{ Group } & \multicolumn{2}{|c|}{ After 7 days } & \multicolumn{2}{|c|}{ After 21 days } \\
\hline & Control & Treated & Control & Treated \\
\hline (1) & $51.243 \pm 0.261$ & $58.343 \pm 0.118^{* *}$ & $54.886 \pm 0.979$ & $56.7 \pm 0.157$ \\
\hline$\%$ of change & \multicolumn{2}{|c|}{+13.856} & \multicolumn{2}{|c|}{+3.305} \\
\hline (2) & $256.314 \pm 0.202$ & $57.585 \pm 0.233$ & $55.571 \pm 0.487$ & $60.028 \pm 0.170$ \\
\hline \% of change & \multicolumn{2}{|c|}{+2.257} & \multicolumn{2}{|c|}{+8.020} \\
\hline
\end{tabular}

Group (1): Rats with mean initial weight $=60 \mathrm{gm}$.

*(Significant) $\quad * *$

(Highly significant)

Group (2): Rats with mean initial weight $=120 \mathrm{gm}$.

- All values were expressed as mean \pm standard error.

e- Mean corpuscular haemoglobin (MCH)

The results in table (6) revealed a high significant decrease $(\mathrm{p}<0.01)$ on $(\mathrm{MCH})$ in group (1) after 7 and 21 days. On the other hand the results exhibited a significant increase $(p<0.05)$ in group (2) after 7 days.

Table (6): Effect of amaranth on MCH (pg) of male albino rats.

\begin{tabular}{|c||c|c||c|c||}
\hline \multirow{2}{*}{ Group } & \multicolumn{2}{|c|}{ After 7 days } & \multicolumn{2}{c||}{ After 21 days } \\
\cline { 2 - 5 } & Control & Treated & Control & Treated \\
\hline \hline$(\mathbf{1})$ & $18.886 \pm 0.201$ & $17.471 \pm 0.156^{* *}$ & $19.657 \pm 0.174$ & $18.929 \pm 0.211^{*}$ \\
\hline \hline \% of change & \multicolumn{2}{|c|}{-7.492} & \multicolumn{2}{|c|}{-3.703} \\
\hline \hline$(\mathbf{2})$ & $18.785 \pm 0.241$ & $19.357 \pm 0.121^{*}$ & $18.386 \pm 0.150$ & $18.686 \pm 0.093$ \\
\hline \hline \% of change & \multicolumn{2}{|c|}{+3.034} & \multicolumn{2}{|c|}{+632} \\
\hline
\end{tabular}

Group (1): Rats with mean initial weight $=60 \mathrm{gm}$.

*(Significant) $\quad * *$

(Highly significant)

Group (2): Rats with mean initial weight $=120 \mathrm{gm}$.

- All values were expressed as mean \pm standard error. 


\section{f-Mean corpuscular haemoglobin concentration (MCHC)}

Table (7) showed a highly significant decrease $(\mathrm{p}<0.01)$ of the mean corpuscular haemoglobin concentration in group (1) after 21 days, and exhibited a significant decrease $(\mathrm{p}<0.05)$ in groups (1) and (2) after 7 days, whereas group (2) after 21 days shows different results, the mean corpuscular haemoglobin concentration revealed a highly significant $(\mathrm{p}<0.01)$ increase.

Table (7): Effect of amaranth on MCHC (\%) of male albino rats.

\begin{tabular}{|c|c|c|c|c|}
\hline \multirow{2}{*}{ Group } & \multicolumn{2}{|c|}{ After 7 days } & \multicolumn{2}{|c|}{ After 21 days } \\
\hline & Control & Treated & Control & Treated \\
\hline$\overline{(1)}$ & $31.857 \pm 0.463$ & $29.871 \pm 0.248^{*}$ & $36.257 \pm 0.075$ & $33.257 \pm 0.149^{* * *}$ \\
\hline \% of change & \multicolumn{2}{|c|}{-6.234} & \multicolumn{2}{|c|}{-8.274} \\
\hline$(2)$ & $32.157 \pm 0.249$ & $31.386 \pm 0.170^{*}$ & $32.214 \pm 0.080$ & $33.514 \pm 0.130^{* * *}$ \\
\hline$\%$ of change & \multicolumn{2}{|c|}{-2.398} & \multicolumn{2}{|c|}{+4.035} \\
\hline
\end{tabular}

Group (1): Rats with mean initial weight $=60 \mathrm{gm}$.

Group (2): Rats with mean initial weight $=120 \mathrm{gm}$.

- All values were expressed as mean \pm standard error. * * (Significant) **

(Highly significant)

\section{j- White blood cells count (WBCs)}

Results presented in table (8) showed the alterations of the white blood cells count of rats after amaranth treatment. It showed a significant increase $(\mathrm{p}<0.05)$ in groups (1) and (2) after 21 days.

Table (8): Effect of amaranth on WBCs count $\left(\mathrm{x10}^{3} \mathrm{~mm}^{3}\right)$ of male albino rats.

\begin{tabular}{|c|c|c|c|c|}
\hline \multirow{2}{*}{ Group } & \multicolumn{2}{|c|}{ After 7 days } & \multicolumn{2}{|c|}{ After 21 days } \\
\hline & Control & Treated & Control & Treated \\
\hline (1) & $11.129 \pm 0.582$ & $10.014 \pm 1.000$ & $11.557 \pm 0.0568$ & $13.657 \pm 0.420$ \\
\hline \% of change & \multicolumn{2}{|c|}{-10.019} & \multicolumn{2}{|c|}{+18.171} \\
\hline 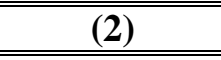 & $11.757 \pm 0.321$ & $10.929 \pm 0.432$ & $12.671 \pm 0.208$ & $14.800 \pm 0.433$ \\
\hline$\%$ of change & \multicolumn{2}{|c|}{-7.043} & \multicolumn{2}{|c|}{$\begin{array}{r}+16.802 \\
\end{array}$} \\
\hline
\end{tabular}

Group (1): Rats with mean initial weight $=60 \mathrm{gm}$.

*(Significant)

Group (2): Rats with mean initial weight $=120 \mathrm{gm}$.

- All values were expressed as mean \pm standard error.

\section{3-Effect of amaranth on biochemical parameters}

\section{a- Aspartate aminotransferase (AST) activity}

Data represented in table (9) displayed the effect of amaranth on serum aspartate aminotransferase (AST) activity, and showed a highly significant $(\mathrm{p}<0.01)$ increase of all groups (1\&2) after 7 and 21 days. 
Table (9): Effect of amaranth on serum AST activity ( $\mu / \mathrm{l})$ of male albino rats.

\begin{tabular}{|c|c|c|c|c|}
\hline \multirow{2}{*}{ Group } & \multicolumn{2}{|c|}{ After 7 days } & \multicolumn{2}{|c|}{ After 21 days } \\
\hline & Control & Treated & Control & Treated \\
\hline$(\mathbf{1})$ & $148.143 \pm 2.375$ & $248.286 \pm 2.135^{* *}$ & $158.857 \pm 1.243$ & $199.000 \pm 2.204^{* *}$ \\
\hline$\%$ of change & \multicolumn{2}{|c|}{+67.599} & \multicolumn{2}{|c|}{+25.269} \\
\hline (2) & $162.429 \pm 1.510$ & $244.429 \pm 3.401^{* *}$ & $150.429 \pm 1.757$ & $229.429 \pm 2.553^{*}$ \\
\hline \% of change & \multicolumn{2}{|c|}{$\begin{array}{l}11.483 \\
+50.48\end{array}$} & \multicolumn{2}{|c|}{+52.516} \\
\hline
\end{tabular}

Group (1): Rats with mean initial weight $=60 \mathrm{gm}$.

**(Highly significant)

Group (2): Rats with mean initial weight $=120 \mathrm{gm}$.

- All values were expressed as mean \pm standard error.

\section{b- Alanine aminotransferase (ALT) activity}

Table (10) displayed that administration of amaranth into male albino rats at a dose $50 \mathrm{mg} / \mathrm{kg} \mathrm{b}$. w. /day did not alter the activity of serum alanine aminotransferase (ALT), and showed non significant changes.

Table (10): Effect of amaranth on serum ALT activity $(\mu / \mathrm{l})$ of male albino rats.

\begin{tabular}{|c|c|c|c|c|}
\hline \multirow{2}{*}{ Group } & \multicolumn{2}{|c|}{ After 7 days } & \multicolumn{2}{|c|}{ After 21 days } \\
\hline & Control & Treated & Control & Treated \\
\hline (1) & $62.429 \pm 0.841$ & $60.714 \pm 1.169$ & $60.285 \pm 0.426$ & $58.000 \pm 1.234$ \\
\hline \% of change & \multicolumn{2}{|c|}{-2.747} & \multicolumn{2}{|c|}{-3.790} \\
\hline$(2)$ & $63.000 \pm 1.113$ & $60.571 \pm 1.212$ & $63.857 \pm 0.469$ & $62.429 \pm 1.462$ \\
\hline$\%$ of change & \multicolumn{2}{|c|}{-3.856} & \multicolumn{2}{|c|}{-2.236} \\
\hline
\end{tabular}

Group (1): Rats with mean initial weight $=60 \mathrm{gm}$.

Group (2): Rats with mean initial weight $=120 \mathrm{gm}$.

- All values were expressed as mean \pm standard error.

\section{c- Alkaline phosphatase (ALP) activity}

The results in table $(11)$ recorded a highly significant increase $(\mathrm{p}<0.01)$ of serum ALP activity in groups (1) and (2) after 7 days, and in group (1) after 21 days.

Table (11): Effect of amaranth on serum ALP activity $(\mu / \mathrm{l})$ of male albino rats.

\begin{tabular}{|c|c|c|c|c|}
\hline \multirow{2}{*}{ Group } & \multicolumn{2}{|c|}{ After 7 days } & \multicolumn{2}{|c|}{ After 21 days } \\
\hline & Control & Treated & Control & Treated \\
\hline$(\mathbf{( 1 )}$ & $108.429 \pm 0.841$ & $203.429 \pm 3.436^{* * *}$ & $140.143 \pm 1.455$ & $223.571 \pm 4.236^{* *}$ \\
\hline$\%$ of change & \multicolumn{2}{|c|}{+87.615} & \multicolumn{2}{|c|}{+59.531} \\
\hline$\overline{(2)}$ & $181.857 \pm 2.087$ & $203.000 \pm 3.572^{* * *}$ & $192.286 \pm 2.447$ & $190.429 \pm 2.458$ \\
\hline$\%$ of change & \multicolumn{2}{|c|}{+11.626} & \multicolumn{2}{|c|}{-0.966} \\
\hline
\end{tabular}

Group (1): Rats with mean initial weight $=60 \mathrm{gm}$.

Group (2): Rats with mean initial weight $=120 \mathrm{gm}$.

**(Highly significant)

- All values were expressed as mean \pm standard error. 


\section{d-Serum content of urea}

Serum content of urea was determined to study the effect of amaranth on kidney function. Data presented in table (12) showed a significant increase $(\mathrm{p}<0.05)$ in group (1) after 7 days. Also, in group (2) after 7 days there was a highly significant increase $(\mathrm{p}<0.01)$. Non significant changes were noted after 21 days in both groups.

Table (12): Effect of amaranth on serum urea content ( $\mathrm{mg} / \mathrm{dl})$ in male albino rats.

\begin{tabular}{|c|c|c|c|c|}
\hline \multirow{2}{*}{ Group } & \multicolumn{2}{|c|}{ After 7 days } & \multicolumn{2}{|c|}{ After 21 days } \\
\hline & Control & Treated & Control & Treated \\
\hline (1) & $53.714 \pm 3.490$ & $73.286 \pm 3.357$ & $56.000 \pm 1.309$ & $57.429 \pm 1.863$ \\
\hline$\%$ of change & \multicolumn{2}{|c|}{+36.437} & \multicolumn{2}{|c|}{+2.552} \\
\hline (2) & $49.171 \pm 1.967$ & $74.143 \pm 3.453^{*}$ & $53.143 \pm 2.251$ & $57.571 \pm 1.307$ \\
\hline$\%$ of change & \multicolumn{2}{|c|}{+50.786} & \multicolumn{2}{|c|}{+8.325} \\
\hline
\end{tabular}

Group (1): Rats with mean initial weight $=60 \mathrm{gm}$. significant)

$*$ (Significant) $\quad * *$ (Highly

Group (2): Rats with mean initial weight $=120 \mathrm{gm}$.

- All values were expressed as mean \pm standard error.

\section{e- Serum uric acid content}

Table (13) indicated a significant increase $(\mathrm{p}<0.05)$ of serum content of uric acid in group (2) after 7 days, but after 21 days the results recorded a high significant decrease $(\mathrm{p}<0.01)$ in groups (1) and (2).

Table (13): Effect of amaranth on serum uric acid content (mg/dl) in male albino rats.

\begin{tabular}{|c||c|c|c|c|}
\hline \multirow{2}{*}{ Group } & \multicolumn{2}{c||}{ After 7 days } & \multicolumn{2}{c|}{ After 21 days } \\
\cline { 2 - 5 } & Control & Treated & Control & Treated \\
\hline \hline$(\mathbf{1})$ & $0.971 \pm 0.075$ & $0.986 \pm 0.116$ & $1.000 \pm 0.076$ & $0.600 \pm 0.031^{* *}$ \\
\hline \hline \% of change & \multicolumn{2}{|c|}{+1.544} & \multicolumn{2}{|c|}{-40.000} \\
\hline \hline$(2)$ & $0.671 \pm 0.084$ & $1.029 \pm 0.113^{*}$ & $0.629 \pm 0.057$ & $0.370 \pm 0.023^{* *}$ \\
\hline \hline \% of change & \multicolumn{2}{|c|}{+53.353} & \multicolumn{2}{|c|}{-41.000} \\
\hline
\end{tabular}

Group (1): Rats with mean initial weight $=60 \mathrm{gm} . \quad$ * (Significant) $\quad * *$ (Highly significant)

Group (2): Rats with mean initial weight $=120 \mathrm{gm}$.

- All values were expressed as mean \pm standard error.

\section{f- Serum creatinine content}

In table (14), group (1) after 21 days showed a significant decrease $(p<0.05)$ on serum creatinine content. On the other hand, group (2) after 21 days showed a highly significant $\quad(p<0.01)$ increase. 
Table (14): Effect of amaranth on serum creatinine content (mg/dl) in male albino rats.

\begin{tabular}{|c||c|c|c|c|}
\hline \multirow{2}{*}{ Group } & \multicolumn{2}{|c|}{ After 7 days } & \multicolumn{2}{c|}{ After 21 days } \\
\cline { 2 - 5 } & Control & Treated & Control & Treated \\
\hline (1) & $0.234 \pm 0.009$ & $0.224 \pm 0.015$ & $0.279 \pm 0.022$ & $0.207 \pm 0.011^{*}$ \\
\hline \hline \% of change & \multicolumn{2}{|c|}{-4.173} & \multicolumn{2}{|c|}{-25.806} \\
\hline \hline (2) & $0.241 \pm 0.015$ & $0.229 \pm 0.014$ & $0.294 \pm 0.008$ & $0.376 \pm 0.012^{* *}$ \\
\hline \hline \% of change & \multicolumn{2}{|c|}{+4.979} & \multicolumn{2}{|c|}{+27.891} \\
\hline
\end{tabular}

Group (1): Rats with mean initial weight $=60 \mathrm{gm} . \quad$ *(Significant) $\quad * *$ (Highly significant)

Group (2): Rats with mean initial weight $=120 \mathrm{gm}$.

- All values were expressed as mean \pm standard error.

\section{Discussion:}

Chemicals have been used to preserve food and to add color and taste to food for centuries. Following the considerable increase in the use of food additives in processed foods from the mid-twentieth century, safety assessment of food additives has been conducted on a formal basis at national and international levels. Currently, over 400 additives are listed by the International Codex Alimentarius for use in food traded around the world. Current approaches to the safety assessment of food additives generally require an extensive database of metabolic and toxicity studies to be generated. Toxicity studies are usually conducted in laboratory animals. Azo dyes have since been found carcinogenic in a wide variety of experiments worldwide, but they are still used in our food and cosmetics.

The present study is concerned to assess the effect of amaranth (azo dye) on some haematological and biochemical parameters in male albino rats.

\section{1-Effect of amaranth on growth performance of rats}

The present study revealed a significant decrease in the percentage of body weight change of rats after treatment with $50 \mathrm{mg}$ amaranth $/ \mathrm{kg}$ b.w. /day for 7 and 21 days as compared with the control rats. These observations were in agreement with Ghoneim (1987) and Shaker et al. (1989). This effect in growth is thought to be due to a reduced availability of nutrients caused by the rapid transit of amaranthcontaining chyme through the upper segments of the gastrointestinal tract
(Ershoff and Thurston, 1974; Aritsuka et $a l .$, 1989; and Takeda et al., 1992) and to colorant's inhibitory effects on the processes of digestion and absorption (Takeda et al., 1992). Moreover, Ashoush (2004) reported that the rat's administration of tartrazine with doses level $(7.5$ \& $75 \mathrm{mg} / \mathrm{kg}$ b.w.) showed decline in body weight gain after two weeks of treatment and then became normal in body weight at the end of experiment, and in 2005, the results of Attia et al. revealed a significant decrease in growth rate percentage of rats up to 7 weeks of benzene sulfonic acid (BSA) supplementation.

However, there are many reports on weight loss in carmoisine or sunset yellow administered experimental animals (Abu El- Zahab et al. 1997; El-Shamy et al., 1999; Marie et al., 1999; Helal et al., 2000 and yassin, 2006). Meanwhile, Osman et al. (1995) found that the synthetic food colorants caused a significant increase in the body weight gain of mice until the fourth month, followed by a significant decrease.

\section{2-Hematological parameters}

Haematological parameters are a valuable tool for assessing the injuries that caused by certain substances. Results of the present investigation revealed that amaranth caused a high significant decline in erythrocyte count and haemoglobin content $(\mathrm{Hb})$, also WBCs showed a significant increase after 21 days. In agreement with the present work, Mason et al. (1974) demonstrated a reduction of haemoglobin when carmoisine was administered to the diet of mice. Furthermore, by long-term 
feeding study on Red $2 \mathrm{G}$ dye at the dose of $130 \mathrm{mg} / \mathrm{kg}$ b.w. /day in the mouse and 32 $\mathrm{mg} / \mathrm{kg}$ b.w. /day in the rat, the spleen showed enlargement with an increased deposition of iron. In the mouse, accelerated erythropoiesis was observed and the rats showed necrosis of elastica. Above $0.5 \%$ of dye in the diet, adverse effects were observed in the spleen, liver and bone marrow. Heinz body formation in the erythrocytes was also observed in both species of rodents (rats\& mice) (WHO, 1981). In the same aspect, Abu El-Zahab et al. (1997) mentioned that rats supplemented with sunset yellow, carmoisine and brilliant blue for 60 days exhibited a significant decrease in haemoglobin content as well as red cell count. These changes induced by food colorants may be due to the prevention of red blood cell synthesis via inhibition of erythropoiesis in the bone marrow.

On the other hand, Shaker et al. (1989) noted an increase in haematological content of rats received $0.1 \%$ chocolate brown colour $(0.1 \% \mathrm{w} / \mathrm{w})$ consisting of tartrazine, noval coccine, carmoisine and indigocarcarmine. While, Hooson et al. (1975) found that indigocarmine had no effect on the total erythrocytic count. Moreover, Ford et al. (1987) stated that carmoisine (given in high doses for 6 months) did not cause any changes in the hematological investigations of rats. Also, Borzelleca \& Hallagan (1988) using tartrazine in high doses and long terms on rats revealed insignificant effects on the haematological parameters of these animals.

\section{3-Biochemical parameters}

\section{a- AST \& ALT activities}

The results of the present study on rats showed that treatment with $50 \mathrm{mg} / \mathrm{kg}$ b.w. /day of amaranth for 7 and 21 days administration caused a highly significant increase of serum AST level (aspartate aminotransferase). On the other hand showed an insignificant change of ALT (alanine aminotransferase) activity. These changes in liver function attributed to hepatocellular impairment which subsequently caused the release of greater than normal levels of intracellular enzymes into the blood. Elevated levels of the transaminases can signal hepatic disease, muscular dystrophy, and organ damage. Thus serum aminotransferases activities are known as toxicity markers in the study of hepatotoxicity caused by chemicals (Govindwar and Dalvi, 1990).

These findings are in harmony with those obtained by Ghoneim (1987) who reported the effects of some synthetic dyes commonly used as food-additives, mainly tartrazine, on some biological and biochemical effects in the experimental animals that showed significantly increase in GOT (AST) in both plasma and liver homogenates. Also, Abdel-Rahim et al. (1989) found a significant increase in both serum AST and ALT of rats fed on chocolate brown HT for three months, and they attributed these changes in liver function to hepatocellular impairment which subsequently caused the release of greater than normal levels of intracellular enzymes into the blood. Furthermore, Abu El-Zahab et al. (1997) investigated the effect of three different synthetic chocolate colorant agents in rats whose diets were supplemented with chocolate colors A and B (sunset yellow, tartrazine, carmoisine and brilliant blue in varying concentration), which revealed a significant increase in serum aspartate and alanine transaminases (AST and ALT respectively). Ashoush (2004) mentioned that tartrazine coloring agent induced a significant elevation in AST and ALT enzymes after 60 days from treatment with $7.5 \mathrm{mg} / \mathrm{kg} \mathrm{b.w/} \mathrm{day.} \mathrm{In}$ addition, Attia et al. (2005) showed significant increase in the activity of the serum enzymes ALT and AST of benzene sulfonic acid sodium (BSA)-treated rats, it may be taken as a good index for disturbance in the liver function.

On the other hand Borzelleca and Hallagan (1988) and Ford et al. (1987) stated that tartrazine and carmoisine caused insignificant changes in rat serum AST and ALT. Yet these contradictory results were recorded after long-term (1-2years) toxicity studies which may indicate an adaptation mechanism on the part of the liver. While, Salah (1994) found that the synthetic food colorants inhibited the activity of GOT, 
GPT and alkaline phosphatases of liver and heart tissues of female and male mice relative to the control. He also found that the sunset yellow, tartrazine, carmoisine and brilliant blue were more hepatotoxic than indigocarmine and brown HT, as the liver enzymes failed to return to normal after 30 days stoppage.

\section{b- ALP activity}

A rise in the alkaline phosphatase (ALP) occurs with all forms of cholestasis, particularly with obstructive jaundice. It is also elevated in diseases of the skeletal system such as hyperparathyroidism, rickets and osteomalacia, as well as fractures and malignant tumors. The present study recorded an elevation in alkaline phosphatase (ALP) activity in rats treated with amaranth.

In the same aspect, Attia et al. (2005) recorded a significant increase in the activity of the serum alkaline phosphatase (ALP) of BSA-treated rats. The increase in ALP activity is attributed to early cholestatic liver damage which primary effects the liver parenchyma and is a key for an early diagnosis of infiltrative diseases (El-Elaimy and El-Nabi, 1990). However, the increased serum activity of ALP is not specific only for liver tissues but also many other tissues may be affected especially the gastrointestinal tract, the intestinal microvilli membrane is rich in ALP (Young et al., 1981; Mahmood et al, 2005). El-Shamy et al. (1999) observed a significant increase in serum ALP in rats treated with a green-coloring dye. Also, Abu El-Zahab et al. (1997) investigated the effect of chocolate colors (sunset yellow, tartrazine, carmoisine and brilliant blue in varying concentrations), which revealed a significant increase in serum alkaline phosphatase (ALP). On the other hand Borzelleca and Hallagan (1988) and Ford et al. (1987) stated that tartrazine and carmoisine caused insignificant changes in rat serum ALP.

\section{(c) Urea, creatinine and uric acid}

The present investigation showed an increase in serum urea content, and serum uric acid level showed an increase after 7 days, but it showed a decrease after 21 days. In addition, serum creatinine level after 21 days exhibited increase in group (2), and on the other hand it showed a decrease in group (1). The abnormal outcomes in the present study could have resulted from kidney function impairment such as degeneration in the proximal convoluted tubules. In this view ElGengaihy et al. (1993) found that the administration of food additives to rats induced early degeneration in the proximal convoluted tubules. Also, Ford et al. (1980) and Oslen et al. (1986) reported nephrotoxicity and severe kidney damage in rats whose diet was supplemented with coloring additives. In addition, El-Shamy et al., 1999 and Helal et al., 2000 recorded an increase in both urea and creatinine in rats treated with tartrazine and brilliant blue mixture, as well as amaranth and orange II (Al-Sharkawi et al., 1996). Further, Attia et al. (2005) reported a significant increase in the concentrations of serum creatinine and uric acid after seven weeks administration of BSA to rats was observed.

While, Chambers et al. (1966) and Carpanini et al. (1978) found that chocolate brown HT had no effect on renal function after both short-term and long term toxicity studies in rats. Also, Ford and Coworkers (1987) found insignificant changes in blood urea in rats fed on carmoisine. Besides, Abu El-Zahab et al. (1997) found that blood urea and serum creatinine in rats suplmented with synthetic food colors remained unchanged throughout the experiment. Finally, Ashoush (2004) found that tartrazine when examined at different doses to male albino rats did not cause any significant differences in creatinine content throughout the experimental course. But the urea content was declined in rats treated with tartrazine at $7.5 \& 75 \mathrm{mg} / \mathrm{kg}$ b.w after 90 days of treatment.

From the current study, it can be concluded that synthetic food colorant agent amaranth induce many alteration in haematological and biochemical parameters in treated rats such as anaemia, liver dysfunction and kidney impairment.

Finally, I would like to express my deepest gratitude to Proff. Shadia Ali Radwan, Dr. 
Ahmed Ryad El-Sayed and Dr. Mohammed Salah Al-Shinnawy for their supervision and guidness of this work.

\section{References:}

1. Abdel-Rahim EA, Ashoush YA, Afify AS and Hewedi F (1989): "Effects of some synthetic food additives on blood hemoglobin and liver function of rats." Minufiya J. Agric. Res., 14 (1), 557.

2. Abicht K, EL-Samalouti V, Junge W, Kroll M, Luthe $H$ and Treskes, M. (2001): Multicenter evaluation of new GGT and ALP reagents with new reference standardization and determination of $37 \mathrm{C}$ reference intervals. Clin Chem. Lab. Med., 39 special supplement, PP 346.

3. Abu El-Zahab HSH, El-Khyat Z, Sidhom G, Awadallah R, Abdel-al W and Mahdy K (1997): Physiological effects of some synthetic food coloring additives on rats. Boll. Chim. Farm., 136(10): 615-627.

4. Al-Sharkawi IM, Mansour MA and ElFiky BK(1996): Non-permitted food colorant in the food products sold in the local market of Tanta city and the physiological departmention of their short term oral intake on liver and kidney functions. J. Union Arab Biol. A, 6: 351371.

5. Andrianova MM (1970): Carcinogenous properties of red food pigments - amaranth, SX purple and 4R purple. Vop. Pitan., 29: 61-65.

6. Aritsuka T, Tanaka $\mathbf{K}$ and Kiriyama $\mathbf{S}$ (1989): Protection of amaranth FD and C Red No. 2 toxicity by beet dietary fiber and its ability to slow down small intestinal transit speed in rats. Nippon Nogeikagaru Kaishi., 63: 1213-1219.

7. Ashoush IS. (2004): A study on side effects of some additives used in food processing. Food Science Dept., Faculty of Agriculture, Ain Shams University.

8. Attia ZI, Basyuni MA, Hegazi MA and Okba SG (2005): Effect of benzene sulfonic acid, the degraded derivative of the sunsetyellow beverages, coloring dyes on the physiology and growth rate of young rats. Egypt. J. Zool., 45: 373-387.

9. Bartels H., Bohmer M. and Hiederli C. (1972): Serum kreatininbestimmung ohne enteiweissen. Clin. Chim. Acta; 37: 193.

10. Bautista ARPL, Moreira ELT, Batista MS, Miranda MS and Gomes ICS (2004): Subacute toxicity assessment ofannatto in rat. Food Chem. Toxicol., 42(4): 625-629.
11. Bergmeyer HU, Horder $M$ and Rej $R$ (1985): Approved recommendation of IFCC methods for the measurement of Catalytic Concentration of enzymes. Part 2. IFCC Method for aspartate aminotransferase. Clin Biochem., 24: 497-510.

12. Borzelleca JF And Hallagan JB (1988):

A chronic toxicity/carcinogenicity study of FD \& C Yellow No. 5 (tartrazine) in mice. Food Chem Toxicol., 26(3):179-194.

13. Carpanini FMB, Butler worth KR, Gaunt IF, Kiss IS, Grasso $P$ and Ganqolli SD (1978): long-term toxicity, $\mathrm{v}$ studies on chocolate brown Ht in rats. Toxicology 11 (3), 303.

14. Chambers PL, Hunter CG and Stevenson DE (1966): short-term study of chocolate brown HT in rats. Fd comet. Toxicol., 4: 155 .

15. Collins TF and McLoughlin J (1972): Teratology studies on food colourings. Part I. Embryotoxicity of amaranth (FD \& C red No. 2) in rats. Fd Cosmet. Toxicol., 10:619-624.

16. Collins TF, Black TN and Ruggles DI (1975b): Long-term effects of dietary amaranth in rats. II. Effects on fetal development, Toxicology, 3: 129-140.

17. Collins TF, Keeler HV, Black TN and Ruggles DI (1975a): Long-term effects of dietary amaranth in rats. I. Effects on reproduction, Toxicology, 3: 115-128.

18. Collins TF, McLaughlin $\mathbf{J}$ and Gray GC (1973): Teratology studies on food colourings. Part II. Embryotoxicity of $\mathrm{R}$ salt and metabolites of amaranth (FD \& C Red No. 2) in rats, Fd. Cosmet Toxicol., 11: 355-365.

19. Dacie JV and Lewis SM (1991): Practical hematology. $7^{\text {th }}$ Ed., The English Language book society and Churchill living stone. PP, 3758.

20. Dacie JV and Lewis SM (1993): Calculation of red blood cells, hemoglobin and erythrocyte indices in: Practical hematology. Churchill living stone. PP, 37-113.

21. El-Elaimy A and El-Nabi SEH (1990): Influence of thiola on pesticide induced intoxication. II. Preventive effect of liver damage. J. Environ. Sci., 1: 67-82.

22. El-Gengaihy $\mathbf{T}$, Abd El-Rahman $\mathbf{S}$ and Hamoudah S (1993): Histological and histochemical study on the effect of the antioxidant food additives "BHT" on liver and kidney of albino rats. Egypt. J. Histol., 16(2): 295-302.

23. El-Shamy KAI, Khadr ME, Morsy FA and Hassanin MM (1999): Toxic ffect of some food additives on vital activities of albino rat, 
green colour (tartrazine and brilliant blue). Egypt. J. Zool., 32: 417-440

24. Ershoff BH and Thurston EW (1974): Effects of diet on amaranth (FD \& C Red No.2). Toxicity in the rat, J. Nutr., 104 (7):937942.

25. Ford GP, Stevenson BI and Evans JG (1987): long-term toxicity study of carmoisine in rats using animals e $\sim$; Posed in utero. Fd. Chem. Toxic., 25 (12), 919.

26. Ford SM, Hook JB and Bond JT (1980): The effect of butylated hydroxyanisole and butylated hydroxytoluene on renal function in the rat. 1- Effect on fluid and electrolyte excretion. Food Cosmet.Toxicol., 18:15-23.

27. Ghoneim NMM (1987). Biokhemical studies on some food additives. Ph.D. thesis. Faculty of Agriculture. Cairo University, Egypt. 28. Govindwar SP and Dalvi RR (1990): Age dependent toxicity of acorn extract in young and old male rats. Vet. Hum. Toxicol., 32:23-6.

29. Gray CH, Haworth PJN and Rinsler MG (I985): Clinical Chemical Pathology. $10^{\text {th }}$ edition, English Language Book Society Inc., London, pp. 73- 94.

30. Helal EGE, Zaahkouk SAM and Mekkawy HA (2000): Effect of some food colorants (synthetic and natural products) of young albino rats I- Liver and kidney functions. The Egypt. J. Hosp. Med., 1: 103 - 113.

31. Hooson J, Gaunt IF, Kiss IS, Grasso P and Butterworth KR (1975): long-term toxicity studies of indigo - carmine in mice. Fd. Cosmet. Toxicol., 13 (2), 167.

32. Kitamura Y, Nishikawa A, Furukawa F, Nakamura H, Okazaki K, Umemura T, Imazawa $T$ and Hirose $M$ (2003): $A$ subchronic toxicity study of shea nut color in Wisterrats. Food Chem. Toxicot., 41(11): 15371542 .

33. Mahmood S, Kaur K, Mittal $\mathbf{N}$ and Mahmood A (2005). Giaraia lamblla: expression of alkaline phosphatase activity in infected rat intestine. Exp Parasitol., 110(2): 9195. .

34. Marie MS, Agag BI, El-Kholi MMA (1999): Physiological and biochemical responses induced by the synthetic food coloring additives tartrazine and ponceau 4R (new coccine) in rats. Egypt- J. Zool., 32: 183201.

35. Mason PL, Gaunt IF, Butter worth KR, Hardy J, Kiss IS and Grasso P (1974): longterm toxicity studies of carmoisine in mice. Fd. Cosmet. Toxicol., 12:601.

36. Neumann U and Ziegenhorn J (1977): Scand J Clin Lab Invest; 37, supplement 147: Abstract 97.
37. Oslen P; Meyer O; Bille $\mathbf{N}$ and Wurtyen G (1986): Carcinogenicity study on BHT in wister rat exposed in utero- Food Cosmet. Toxicol., 24: 1-18.

38. Osman MA, Afifi A, Hussein RM, Kamilia B, Abdel Aziz and Salah SH (1995): Long-term biochemical and genotoxicity studies of four synthetic food and drug colorants in mice- Bull. Fac. Pharm. Cairo Univ., 33(1): 1321.

39. Paumgartten FJR, De-Carvalho RR, Araujo IB, Pinto FM, Borges OO, Souza CAM and Kuriyama SN (2002): Evaluation of the developmental toxicity ofannatto in the rat. Food Chem. Toxicol., 40(11): 1595-1601.

40. Rodak LC (1995): Routine testing in hematology. In: Diagnostic hematology. W.B. London, Toronto. PP, 128-144.

41. Salah SH (1994): Biochemical studies on some synthetic food colorants. M. Sc. Thesis, Faculty of Agriculture, Cairo University, Cairo, Egypt.

42. Shaker AMH, Ismail IA and El-Nemr SE (1989): Effect of different food stuff colorants added to casein diet for biological evalutation. Bull. Nutr, Isnt. Cairo, Egypt. 9(1): 77-86.

43. Snedecor GW and Cochran WG (1980): Statistical methods. Oxford and J. 13. H. Publishing Co., $7^{\text {th }}$ Ed.

44. Takeda H, Nakajima A and Kiriyama $\mathbf{S}$ (1992): Beneficial effects of dietary fiber on the upper gastrointestinal transit time in rats suufering from a toxic dose of amaranth. Biosci. Biotech. Biochem., 56: 551-555.

45. Town, M. H.; Gehm, S.; Hammer, B. and Ziegenhorn, J. J. (1985): Asensitive colorimetric method for the enzymatic determination of uric acid. Clin. Chim., 23: 591. 46. WHO (1981): Toxicological evaluation of certain food additives and contaminants. Food Additive Series No. 16, World Health Organization, Geneva.

47. Willheim $R$ and Ivy AC (1953): A preliminary study concerning the possibility of dietary carcinogenesis, Gastroenterology, 23:119.

48. Yassin HM (2006): Molecular biological effects of a food colorant commonly used in Egypt on white mouse. Department of Biological and Geological Sciences. Faculty of Education, Ain Shams University.

49. Young GP, Yeldin ST and Alpers DH (1981): Distribution of soluble and membranous forms of alkaline phosphatase in the small intestine of the rat. Biochimica Biophysica Acta., 676: 257-265. 


\title{
التغيرات الدموية و الكيموحيوية الناجمة عن تأثير الأمارانث فى ذكور الجرذان البيضاء البهاء
}

\author{
شادية على رضوان - أحمد رياض السيد - محمد صلاح الثناوى \\ - أمنية نصر عبدالرحمن محمد لياضل \\ قسم العلوم البيولوجية والجيولوجية-كلية التربية- جامعة عين شمس ملئس
}

يشيع استخدام مضافات الطعام فى مجالات عديدة لصناعة الأغذية على مستوى العالم , ولذلك تهدف

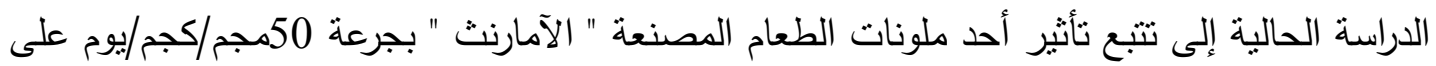
ذكور الجرذان البيضاء لفترتين ( 7 و 21 يوم ) لمجموعتين مختلفتي الوزن (60 و 120 جرام ) وذلك بالحقن داخل الغثاء البريتونى. ووزنت الجرذان أثناء التجربة و فى نهايتها , وتم الحصول على عينات الدم لجرذان كل مجموعة على حدة (60 و 120 جرام ) فى اليوم السابع و الحادي و العشرون بعد الحقن • ونم دراسة المعايير الدموية مثل عدد كريات الدم الحمراء (RBC) ونسبة الهيموجلوبين (Hb) ونسبة الهيماتوكريت (Hct) ومتوسط حجم كرات الدم (MCV) والهيموجلوبين النسبى لعدد كريات الدم الحمراء وتركيز الهيموجلوبين النسبى لعدد كريات الدم الحمراء (MCHC) الكيموحيوية وشملت إنزيم إسبرتيت أمينوترانسفيريز (AST) وإنزيم آلانين أمينوترانسفيريز (ALT) وإنزيم الفوسفاتيز القاعدى (ALP) والكرياتينين و اليوريا و حمض اليوريك.

و أظهرت النتائج نقصا معنويا فى وزن جسم الجرذان بعد المعاملة بالآمارنث (50مجم/كجم/يوم) مقارنة بمجموعة الجرذان الضابطة ـ و أيضا فى عدد كريات الدم الحمراء(RBCs) ، ونسبة الهيموجلوبين ونسبة الهيماتوكريت (Hct) بينما حدثت زيادة في متوسط حجم كريات الام الحمراء (HCV) كريات الدم البيضاء ( WBCs ) م كما أوضحت النتائج زيادة معنوية فى إنزيم إسبرتيت أمينوترانسفيريز AST والفوسفاتيز القاعدى ALP ومحتوى اليوريا فى المجموعات المعاملة ـ بينما ارتفع محتوى حمض إنس اليوريك بعد 7 أيام ولكنه قد انخفض بعد 21 يوم من المعاملة ـ و نستتنج من نتائج البحث أن ملونات لئن

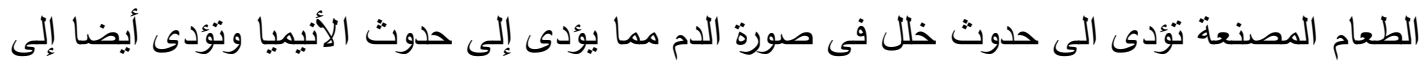
خلل فى وظائف الكبد والكلية , ونوصى بإعادة النظر فى كمية الجرعات المستخدمة من الملونات المصنعة عند إضافتها أثناء صناعة الأطعمة والمشروبات . 